\title{
A OBRA DE ARTE COMO OBJETO COMUM
}

\author{
Filipe Ferreira Pires Völz ${ }^{1}$ \\ Universidade Federal do Rio de Janeiro (UFRJ) \\ (D) https://orcid.org/0000-0001-6997-4522
}

\section{RESUMO:}

O objetivo deste artigo é relacionar o ready-made de Duchamp - uma obra de arte que é idêntica a um objeto comum - com a história da arte que o precedeu e entender de que modo sua ruptura radical já estava dentro dessa história. Inicio com uma introdução ao e interpretação do ready-made. Em seguida, me respaldando em Gombrich, Greenberg e outros, examino os três tipos de arte na história propostos por Peter Bürger, focando na questão da realidade/irrealidade da obra, aos poucos me aproximando da relação da obra com seu caráter de objeto. Meu ponto principal é que a bidimensionalidade do quadro reforça a existência da tela (ou do suporte em questão) e assim também a relação de sua experiência com o mundo concreto em que o quadro se encontra, em contraposição a ilusão dramática do quadro tridimensional. A seguir, examino os impressionistas, onde se inicia um movimento de encontro à realidade da tela, que se radicaliza depois em variadas vertentes do modernismo, onde se encontra Duchamp. Tendo feito este percurso, examino o conceito de vanguarda de Bürger e sua relação com o que ele chama de práxis vital, o mundo fora do quadro ilusionista, que explico através da ideia de distração de Walter Benjamin. Aqui, sugiro pensar o ready-made como uma proposta de transposição da arte e sua teoria ao mundo "não-artístico" das coisas comuns.

PALAVRAS-CHAVE: História da Arte; Arte Moderna;Walter Benjamin.

\section{THE WORK OF ART AS A COMMON OBJECT}

\begin{abstract}
:
The aim of this article is to relate Duchamp's ready-made - a work of art that is identical to a common object - with the history of art that preceded it and to understand how its radical rupture was already contained in that history. I choose to start it with an introduction and interpretation of the ready-made. Then, supported by Gombrich, Greenberg and others, I
\end{abstract}

\footnotetext{
${ }^{1}$ Doutorando em Filosofia pela Universidade Federal do Rio de Janeiro (UFRJ), Brasil. Bolsista CNPq. E-mail: aquelefilipevolz@gmail.com
}

A obra de arte como objeto comum - Filipe Ferreira Pires Völz 
examine the three types of art in history proposed by Peter Bürger, focusing in the question of the reality/unreality of the work, gradually approaching the relation of the work with its character of object. My main point is that the two-dimensionality of the paiting reinforces the existence of the canvas (or of the support in question) and thus also the relation of its experience with the concrete world in which the paiting is found, as opposed to the dramatic illusion of the three-dimensional picture. Hereafter, I examine the impressionists, when its started a movement that goes to the reality of the canvas, which is then radicalized in various aspects of modernism, where Duchamp is found. Having taken this course, I examine Bürger's concept of vanguard and its relation to what he calls the "vital praxis", the world outside the illusionist framework, which I explain through Walter Benjamin's idea of distraction. Here, I suggest to think the ready-made as a proposal of transposition of art and its theory to the "non-artistic" world of the common things.

KEYWORDS: Art History; Modern Art; Walter Benjamin.

\section{Introdução}

Os ready-mades são obras de arte cujo reconhecimento como obra depende unicamente deste próprio reconhecimento. Explico: ready-made é uma obra, como diz o nome, que "já vem pronta", como uma lasanha de micro-ondas. Assim como basta apenas esquentar a lasanha e nada mais, no ready-made é preciso somente o ato de reconhecimento. Dizer "somente" é dizer que esse ato é arbitrário, que não é necessário nada além de seu puro acontecer - sem justificativas - para que ele se validade na obra, e a constitua. De certa maneira, podemos dizer que no ready-made a criação e a recepção da obra são quase a mesma coisa. Marcel Duchamp, o artista francês que criou os ready-mades, é o seu autor porque os reconheceu como obra primeiro, ou seja, foi antes de tudo um espectador deles, como um médium $^{2}$ que vê espíritos invisíveis possuindo coisas comuns. Assim como o sobrenatural, o estatuto de arte do ready-made é indemonstrável, é questão para a fé ou para o jogo (que ao contrário da fé tem consciência de sua arbitrariedade).

O exemplo é sempre mais esclarecedor: concebamos um copo de vidro, usado para beber água, porém de uma forma abstrata, sem ocupar lugar algum no mundo nem executar nenhuma função. Seria improvável se a maioria das pessoas o chamaria de obra de arte imediatamente ou mesmo se requisitada a responder a pergunta sobre esse estatuto. Agora, sobre as mesmas condições genéricas, peço ao leitor que imagine "uma obra de arte". Se o leitor não se forçar a nada, terá imaginado um quadro com uma pintura, possivelmente representativa, pós-renascentista. Talvez não, é uma questão

${ }^{2}$ Em "O Ato Criador" Duchamp, em outro sentido, aproxima médium e artista. 
que permite certa margem - mas temos que saber reconhecer quais objetos viriam primeiro a mente e para a maior parte das pessoas. Por que? Porque é disso que trata o ready-made: das nossas percepções usuais sobre as coisas e do modo como elas são formadas.

Vamos imaginar um urinol, como o que serviu de "receptáculo" para o ready-made mais famoso de Duchamp, A Fonte, de 1917. Ele está deslocado de seu lugar habitual, o banheiro, e ocupa um pedestal, em um museu ou galeria de arte. A assinatura feita com tinta escura "R.Mutt, 1917", sobressai sobre sua superfície branca, provavelmente de porcelana. Nós estamos em 2017, cem anos depois, e muitos de nós já conhecem as peripécias do antigo mestre Duchamp. Já vimos coisas muito piores em nossos museus ou fora deles - um ano de contas de luz enfileiradas na parede, formando uma parábola com a linha medidora nos gráficos dos boletos; uma jovem artista nua cercada dos mais diversos instrumentos permanece calada e em pé depois de anunciar que, durante certo intervalo de tempo, qualquer um pode fazer qualquer coisa com ela; um crânio cravejado de diamantes, um tubarão em formol dentro de um retângulo de vidro, uma turbina de avião ligada no centro de um museu de arquitetura redonda, criando um tornado poderoso. Sem sombra de dúvida, o urinol é uma obra de arte.

Porém, para a maioria das pessoas do mundo, ele continuaria a não ser obra de arte, independente disso tudo, se não fossem a assinatura e, sobretudo, o lugar onde ele se encontra. Por causa disso, um número muito maior de pessoas (basta preencher o requisito de saber reconhecer um museu) poderia entender que o urinol é, ali onde está, uma obra de arte, mesmo que isso causasse confusão ou espanto. Uma pintura, no entanto, não precisa de lugar para ser arte. Podemos imaginar um quadro de forma abstrata, como um mero conceito, e ele será arte para nós. O mesmo não podemos dizer do copo de vidro, do urinol, etc.

$\mathrm{O}$ ready-made não cria uma nova maneira de fazer arte. O que ele faz é lançar uma nova interpretação sobre as formas antigas. Na verdade, nem isso: a interpretação é antiga como a própria arte - o que é novo é a consciência, o reconhecimento dessa interpretação como o que ela é: uma interpretação e nada mais. Basta deslocarmos a pintura - que em si mesma, sem lugar, nos leva a chamá-la de "arte" - para um contexto como, por exemplo, o de uma hipotética tribo distante onde nunca nada como esse quadro tenha surgido. Rapidamente, sua "essência" de arte some. Alguns podem dizer que sua "beleza" permaneceria, etc. Isso não tem muita importância, pois a beleza ou que quer que seja também pode existir em um pôr-do-sol, em um desenho em giz colorido feito por uma criança, em uma canção assobiada displicentemente - e nem por isso chamamos essas coisas de obras de arte. 
"O que é a arte?" 3 parece ter sido a pergunta feita por Duchamp com seus ready-mades dadaístas. Mas esta era, o tempo todo, uma pergunta retórica, com a resposta contida em si de modo invisível, como o estatuto de arte no objeto comum. O que foi respondido? Em nossa interpretação, que não há arte. Há, em seu lugar, o pôr-do-sol, o desenho, a canção. Mas, também, o dia comum, o rabisco vulgar, o ruído. A importância do simples urinol posto em um pedestal reside na abertura, para a teoria da arte, do campo das coisas comuns, mas em um movimento tão radical que essa teoria deixa de ser "da arte". O ready-made não pode nos fazer buscar objetos comuns que possam ser colocados em museus. Também não deve se limitar a análise do quadro como objeto comum, destituído da aura artística, como no caso da hipótese do reciprocal ready-made, levantada pelo próprio Duchamp, onde um quadro de Rembrandt é usado como tábua de passar roupa. O cerne da abertura que o ready-made faz na teoria é a sua conversão de uma teoria da arte em uma teoria das coisas comuns. Uma mudança de objeto de estudo: do quadro que observamos para a camisa que vestimos. Da experiência contemplativa para a fruição distraída. E, é claro, nesta passagem deixam-se tornar objetos de estudo os tipos híbridos: as mercadorias da arte, os produtos da indústria cultural, o kitch, os filmes e as obras de entretenimento.

\section{Análise}

Em seu Teoria da Vanguarda, Peter Bürger (2012, p.93-4) confecciona uma "tipologia histórica" de três elementos, a saber, a arte sacra, a arte cortesã e a arte burguesa. A essas tipos se contraporá adiante a vanguarda, novidade do século XX. Vamos explicar os três primeiros e em seguida os utilizar em uma breve análise histórica da arte, onde encontraremos o germe do ready-made e o seu sentido - momento em que nos deteremos sobre o tema da vanguarda. Além das quatro noções de Bürger, vamos pegar alguns elementos de A Pintura Moderna e A Crise da Pintura de Cavalete, de Clement Greenberg, em especial a noção de bidimensionalidade e tridimensionalidade na pintura.

Segundo Bürger, os tipos são definidos segundo três critérios: finalidade, produção e recepção.

\footnotetext{
${ }^{3}$ Cf. DANTO, 2014, p.48, sobre o ready-made (A Fonte, especificamente): "Mas então qual é o fulcro conceitual dessa obra ainda hoje controversa? Meu ponto de vista é que ele reside na questão que ela põe, a saber, por que - referindo-se a si mesma - deveria isto ser uma obra de arte, se outra coisa exatamente como isto, a saber, aquilo - referindo-se agora à classe dos mictórios irredimidos - é uma peça de ofício hidráulico? (...) Duchamp não só levantou a questão 'o que é arte?', mas, antes, por que algo é uma obra de arte, quando algo exatamente idêntico não o é?"
} 
- Arte sacra é objeto de culto, é produzida de modo coletivo e artesanal e experienciada também de modo coletivo. A arte da alta Idade Média.

- Arte cortesã é objeto de representação, é produzida de modo individual, mas a recepção é coletiva - porém a coletividade "não é mais um conteúdo sacro, mas a sociabilidade". A arte na corte de Luís XIV.

- Arte burguesa é objeto de representação, mas ela representa apenas na medida em que isso é instrumentalizado enquanto expressão da "autocompreensão sobre a própria classe", no caso a burguesia. Produção e recepção individualizadas.

A grande diferença dos dois primeiros tipos para o último se concentra no conceito de "práxis vital" de Bürger. Aquilo que poderíamos chamar de "mundo prático", que se distingue de um "mundo da arte", é vivido coletivamente pelos indivíduos através da práxis. Neste mundo, nós agimos de acordo com finalidades, envolvidas com os desejos e objetivos que elegemos ou acatamos em nossa vida. Cada qual a sua maneira, arte sacra e cortesã estão "incorporadas à práxis vital do receptor", mas a arte burguesa se situa "fora" dessa práxis (BÜRGER, 2012, p. 95). O que isso quer dizer? Veremos no tópico seguinte.

\section{História ${ }^{4}$}

David Hume (2005, p.57) conta, em tom de anedota que na Grécia antiga um homem chamado Stílpon foi condenado por blasfêmia, sob a legislação de uma pólis, ao declarar em público que o famoso escultor Fídias era o autor de uma certa estátua do deus Minerva (Atenas). Fídias, um exímio escultor, havia produzido uma obra maravilhosa. Porém, o encanto da obra só pode servir pra explicar a condenação deste homem se aliado a uma atmosfera de relação com a arte muito distinta da que conhecemos. A obra devia ser bela por certo, mas a arte, de qualquer maneira, não estava encastelada na ficção, mas nutria e era nutrida por esse campo da práxis vital, a vida mesma, a realidade - ou, para um termo menos problemático em filosofia, aquilo que nos faz socorrer um homem infartando na rua, mas aplaudir um homem infartando no palco. A estátua de Minerva era Minerva. Cai dentro do domínio da arte sacra: objeto de

\footnotetext{
${ }^{4}$ A história da arte em questão é aquela que influenciou Duchamp e a qual a criação dos ready-mades tinha algo a dizer. Esta tendência mais "cronológica", que vê uma continuidade entre as diversas épocas, é exemplificada em A história da arte de E.H. Gombrich, que inclui o ready-made e que aqui utilizamos. Autores importantes com interpretações opostas em relação ao ready-made, como Clement Greenberg e Arthur Danto, adotam essa tendência, cada qual a seu modo. O autor está ciente de historiografias paralelas, como a de Pável Floriênski e, mais recentemente, Hans Belting e DidiHuberman.
} 
culto, não de representação. Fídias era um grande escultor, mas atribuir a ele a autoria das peças que produzia era outra questão. Seria dizer que Fídias criou um Deus.

A virtuose grega pode confundir o que está verdadeiramente em jogo na arte - e é pra nos prevenir contra isso que existe o ready-made e que existiram antes na História outras obras que ou não tinham a intenção ou lutavam contra o apuro mimético da arte. No primeiro caso estão, por exemplo, os egípcios, como lembra Gombrich (2013, p. 53):

\footnotetext{
...a arte egípcia baseia-se não no que o artista via num dado momento, mas naquilo que ele sabia pertencer à pessoa ou cena retratadas. (...) $\mathrm{O}$ artista consubstancia na imagem seu conhecimento não somente das formas e contornos, mas também de seu significado.
}

Este exemplo clarifica as coisas: "Nós, às vezes, chamamos alguém de 'grande homem'; os egípcios desenhavam os grandes homens bem maiores que seus servos..." (Idem), ou como coloca Mário Pedrosa: "Desde a época egípcia até fins da Idade Média, as figuras aparecem representadas em tamanhos diferentes, numa escala hierárquica", já que "o maior tamanho expressa o maior poder" (PEDROSA, 2015, p. 540).

Da mesma forma, a bidimensionalidade egípcia exige pra retratar, com o caráter de informação, todas as partes do corpo de uma figura. Ao contrário da arte grega a certa altura, que adota a perspectiva do olhar no desenho da obra (e consequentemente utiliza na obra o recurso técnica da perspectiva), e por isso, como o olhar é sensível, pode por vezes fazer com que não vejamos certas coisas (se olhamos um pé de frente, o calcanhar está oculto e a forma não é aquela que "usualmente" se concebe para um pé), o Antigo Egito produzia obras "inumanas", irrealistas, mas onde, através dessas deformações, no desenho ficavam expostos todos os aspectos do objeto. Todos os pés são desenhados de lado, de modo que o calcanhar sempre aparece, pois o conhecimento de pé engloba o calcanhar. É claro que isso não é uma regra precisa, de modo que o rosto de perfil possui apenas um olho. Porém, como nota Gombrich, este olho está desenhado como se não estive de perfil, apesar do rosto. O olho está retratado como se integrasse um rosto visto de modo frontal, apesar do rosto do em que efetivamente se encontra seja um perfil. Ele é mais um símbolo que significa "olho" do que o desenho de um olho. Na verdade, ele é as duas coisas. Possivelmente uma herança da escrita em hieróglifos, como lembra Floriênski sobre a arte egípcia: "É provável que o seu significado interno não esteja muito distante das inscrições hieroglíficas" (FLORIÊNSKI, 2012, p. 35).

Falamos de um segundo caso além do egípcio, onde se lutaria contra o realismo da arte e a representação, na pintura, do olhar humano. Este é o caso da arte judaico-cristã. Sob esta perspectiva, a blasfêmia não seria o 
bom senso do admirador de Fídias, mas a pólis que o condenou e junto com ela a estátua de Minerva. O Deus judaico-cristão é iconoclasta, destruidor de ícones, como o bezerro de ouro da famosa passagem bíblica, e não admite representação visível de si. Antitéticos a cultura greco-romana, os judeus e primeiros cristãos que viveram na Europa pós-esplendor grego não tem interesse nos "efeitos e truques" que enfeitiçam o espectador, mas queriam uma pintura não-bela ou não-estética, cujo "principal objetivo" fosse "lembrar os fiéis dos exemplos de misericórdia e poder divinos" (GOMBRICH, 2013, p. 99) e não extasiar o olhar do espectador.

É desse espírito que vai nascer a arte da alta idade média que Bürger usa como exemplo de arte sacra. Os gregos queriam produzir artigos belos, mas não queriam confundir a técnica humana com a presença divina ou natural. Nesse sentido, a idade média tenta superar essa confusão de vez, excluindo a beleza da arte, ao menos a beleza realista. Em última análise, realismo na pintura quer dizer ilusão de realismo. Confusão entre realidade criada por deus e (ilusão de) realidade criada pelo homem é o que se procura evitar aqui. Buscasse uma clareza na arte da sua diferença mimética com o real. Além disso, como a natureza é vista como um mundo de corrupção, retratá-la como realmente é parece um problema.

Se desenvolve no final da antiguidade e no período pré-renascentista da idade média um tipo de arte cristã iconoclasta, que hoje conhecemos através de tipologias como arte gótica, arte bizantina etc.. A obra funciona para converter uma população quase inteiramente analfabeta a uma religião que gira em torno de um livro. Porém, ao contrário dos primeiros artistas cristãos, nos períodos posteriores o não realismo não quer dizer necessariamente uma falta de caráter encantatório na obra. Os góticos, por exemplo, procuravam "contar sua história sagrada do modo mais tocante e convincente possível" e viam os truques do estilo como "meios a serviço de um fim" (GOMBRICH, 2013, p.144). O impulso pela iconoclastia se encontra com o impulso pelo encanto.

O que caracteriza propriamente uma obra como essa? Basta olhar para uma como os ícones de Andrei Rublev ou o Cristo Pantocrator, mosaico bizantino na Basílica de Monreale, na Sicília - mas muitos outros exemplos, de períodos e sub-estilos diversos, podem estar contidos na descrição que faremos. Estes dois que citamos tem entre si uma diferença de aproximadamente 200 anos (Rublev é de 1360 ou 70, a igreja é de 1174);

O Pantocrator é uma imagem de Jesus dentro de uma cúpula esférica na Basílica, atrás do altar. Ao fundo da imagem do messias está a própria parede da igreja, como se o messias fosse um grafite num muro. Cristo não está em "lugar nenhum", não tem edificações ao fundo, árvores, os muros de uma prisão, nada, a não ser a pura cor da parede. Isso quer dizer duas coisas diferentes, sendo as duas verdadeiras. Por um lado, que o messias é uma figura abstrata, que ele não está realizando nenhuma ação, não está em nenhum tempo nem espaço, mas apenas sendo o que é, como uma ilustração 
de um candelabro sob um fundo branco de página no verbete "Candelabro" de uma enciclopédia ou dicionário. Por outro lado, assim como poderíamos dizer que a figura do verbete salta para a nossa dimensão, a mesma do livro, objeto físico, ao se situar sobre um fundo que é a própria página branca, o Pantocrator está em um tempo e em um espaço: a própria basílica, no momento em que o vemos. Ao contrário do quadro representativo, a pintura medieval ocupa o mesmo espaço que o espectador, o espaço sagrado da igreja.

Nesse sentido ela é, ao contrário de um quadro ilusionista, bidimensional: o desenho é distorcido e irreal porque se planifica para os lados, ao contrário da imagem viva de uma pessoa em nossa frente, que é tridimensional. Contudo, ao assumir no desenho essa bidimensionalidade, ele se torna, enquanto pintura sobre uma parede, parte do nosso mundo, portanto, tridimensional. Ou seja, o Pantocrator existe de fato e é desenhado de modo a ressaltar essa existência, mas ele existe em nosso mundo, e não num mundo dentro de uma tela. Ele está em nosso mundo como a parede está. Se nós suspendermos nossa interpretação laica, o Cristo está em nosso mundo não como pintura, tal qual a estátua de Minerva, mas como o próprio objeto de culto, a entidade divina presente. "Os bizantinos desmaterializavam a realidade imediata invocando uma realidade transcendente" e "excluíam apelos à experiência literal contra a transcendente" (GREENBERG, 2013, p. 197). Como não está em um quadro, o Cristo atua como algo em parte decorativo, porém "a distinção entre decorativo e não-decorativo tendia a ficar obscurecida" (Idem, p. 196) nesse tipo de arte.

Observamos então duas características dessas obras: o fundo nãorealista e a estrutura do desenho. Ambos são aspectos da ausência da perspectiva e, com ela, da luz, como forma de uso da cor na pintura. A pintura não representa variações de luz, os elementos do quadro não estão em referência a nenhuma ponto de luz, de modo que toda a iluminação do quadro incide igualmente. As cores se diferenciam, mas os tons de cada cor são únicos, sem muitas variações. Entre o centro do rosto do Cristo e as suas laterais não há diferença de distância em relação ao nosso olhar. Isso tudo é irreal, já que ao olhar para um rosto de frente, as orelhas parecem mais ao fundo do que o nariz, ao contrário dessas obras. Orelhas e nariz estão numa mesma distância de nós. De fato, tudo no quadro está numa mesma distância, numa espécie de economia democrática dos elementos do quadro. Tudo vem junto, de uma vez só, para a visão. Este tipo de imagem, apesar de não ser realista, pode ser suficientemente encantadora, e de fato, se notarmos a ausência de perspectiva nos logos e imagens em outdoors e propagandas hoje em dia, com suas cores berrantes e todos os elementos imagéticos agindo ao mesmo tempo sobre nós, podemos compreender isso de forma mais concreta. Não por acaso, o Pantocrator, os ícones de Rublev, 
as pinturas góticas e bizantinas, todas fazem uso intenso e até "exagerado" da cor:

$$
\begin{aligned}
& \text { A pintura e o mosaico bizantinos moveram-se desde o início } \\
& \text { para uma visão de cor integral na qual o papel do contraste } \\
& \text { entre claro e escuro era radicalmente diminuído } \\
& \text { (GREENBERG, 2013, p. 197) }
\end{aligned}
$$

Com a ausência de luz no interior da pintura, a cor não se ajusta as sombras, e age em nossos olhos como pura tinta - sendo interpretada como túnica azul ou auréola dourada mais pelo reconhecimento cognitivo de uma figura do que pela experiência concreta e realista (em outras palavras, tridimensional ou, para usar mais termos de Greenberg, escultural, tátil) de túnica ou auréola.

Além dessas características podemos apontar as inscrições nas obras. Ao lado direito do Pantocrator, ocupando o mesmo plano espacial que ele e seu fundo estão inscrições em grego antigo. As inscrições, como as pichações nos muros de hoje, querem dizer alguma coisa e a sua colocação ao lado do Cristo não deixam dúvida de que o desenho está ali pelo mesmo motivo. Muitas vezes, nessas obras medievais, as palavras designam a figura do desenho, o nome e seu título - no caso desta, "criador do mundo". Dizer alguma coisa não é só informar, mas também possui seu caráter de maravilhamento - e as vezes as palavras nos muros fazem isso conosco também. Além disso, ao ocupar o mesmo plano que a figura, são outra fonte de rompimento com qualquer caráter de ilusão.

Há obras como a Anunciação de Rublev em que há um fundo, uma "realidade", com edificações, montanhas, mas dificilmente um céu: o céu desse mundo é a parede da igreja, de modo que também repete o pertencimento do personagem ao mundo do espectador, não como coisa/pessoa, mas como pintura. $\mathrm{O}$ desenho segue o mesmo princípio, pois as construções (de uma geometria não-euclidiana, poderíamos dizer) são agrupamentos de partes todas colocadas "para a frente" e, como o pé egípcio, trazem todos os componentes do prédio, de uma vez só, aglutinados sobre a superfície do plano bidimensional, quase como se as partes entrassem umas nas outras. Dificilmente algo assim se manteria em pé sobre a força da gravidade.

Como o espaço da igreja é um espaço de culto público e "autoria", nesse tipo de obra, é irrelevante, proibida ou secundária, Bürger chama a recepção e criação da arte sacra de coletivas.

Em resumo, a idade média, escreve Floriênski (2012, p.49),"rompe com os objetivos do ilusionismo" e busca "não a fabricação de simulacros, mas de símbolos da realidade". Já Greenberg sintetiza da seguinte maneira:

$\mathrm{Na}$ arte romana tardia e arte bizantina, os artifícios naturalistas da pintura greco-romana forma invertidos para reafirmar a 
planura do espaço pictórico; a luz e a sombra - os meios por excelência da ilusão escultural - foram estilizadas em padrões planos e usadas para fins decorativos ou quase abstratos em vez de ilusionistas (GREENBERG, 2013, p. 196).

O impulso para o encantamento superou historicamente a exigência de iconoclastia, e passou a exercer sozinho a função sacra "a partir" do Renascimento europeu - as aspas se justificam porque tal período compreende uma faixa de tempo elástica; entre Giotto e Da Vinci, por exemplo, a diferença é de séculos. Com a habilidade da perspectiva, o quadro começou a incorporar a visão humana e com ela o realismo do desenho, a pintura da luz e, com esta última, a variação de tons cromáticos. Os temas persistiam os mesmos, junto da função: no entanto, a parede da igreja não é mais o único ou principal suporte das obras; surge o quadro. Isso é imprescindível, como lembra Greenberg, porque

A pintura de cavalete subordina o efeito decorativo ao dramático. Ela recorta a ilusão de uma cavidade em forma de caixa na parede atrás de si, e dentro desta, como uma unidade, ela organiza aparências tridimensionais. (Idem, p.181)

O quadro, através da organização espacial (perspectiva - existe um fundo do quadro e uma parte mais próxima de nós que o vemos; o quadro possui diversos planos, definidos em seu tamanho pela distância em relação ao centro do quadro), resposta dos elementos a essa organização (luz/sombra e cores) e, paralelamente, da forma do desenho (uma técnica que dá expressão aos rostos, músculos ao corpo, precisão aos gestos), cria uma maravilhosa ilusão de realidade dentro do retângulo do quadro. É como uma janela para outro mundo. Mesmo em obras feitas na parede da igreja, como as de Michelangelo na Capela Sistina, agora parecem tornar a parede parte da realidade ilusória da obra e não o contrário.

Aos poucos entramos na arte cortesã, que, em minha interpretação do que Bürger se refere, começa no renascimento, mas se refere com mais propriedade a estilos futuros, como o rococó, o neoclassicismo, etc. A produção se torna individual, apesar da fruição se dar em espaços públicos ainda. Nasce o autor, agora não mais o artesão anônimo, mas um mestre, uma figura de espírito, um pensador. $O$ quadro ganha cada vez mais mobilidade e passa a ocupar primeiro os salões da realeza e depois palácios de aristocratas ou grandes comerciantes. No norte da Europa, com a conservação, via protestantismo, da iconoclastia, os pintores, não obstante fortemente influenciados pelos mestres italianos, são obrigados a praticar sua técnica com os rostos e corpos de homens comuns ao invés de santos. No geral, esses homens comuns não são tão comuns: fazem parte da elite da sociedade, que pode pagar bem por um quadro. De qualquer forma, um novo tema, além da religião, começa a se tornar possível para a arte. A pintura intensifica sua habilidade em imitar a realidade em seus pormenores 
ao pintar seres humanos concretos e não figuras idealizadas. $O$ que é interessante, contudo, é que nem sempre isso significa um realismo literal ou realismo do desenho, do traço. Vejamos um exemplo posterior ao renascimento.

Juan de Pareja é um dos quadros mais famosos do mestre espanhol Diego Velázquez. Juan está retratado com as mãos a frente do corpo de uma forma parecida com a Mona Lisa de Da Vinci. Mas, se olharmos a mão da pintura de Velázquez e compararmos com a de Da Vinci, uma grande diferença vai se abrir aos nossos olhos. De fato, a mão de Juan parece um borrão marrom, mas isso só fica claro quando a olhamos diretamente, quando focamos somente nela. A mão de Mona Lisa, mesmo com o auxílio do sfumato (que é uma técnica que cria uma leve gradação de tom na linha do desenho, criando um efeito esfumaçado), é muito mais próxima de uma mão, como a que imaginaríamos em um verbete enciclopédico, que procura informar. Contudo, a captura da realidade está mais próxima do mestre espanhol que do florentino: conta-se que Juan de Pareja foi confundido com o Juan que existia de fato. E se compararmos as obras, veremos as diferenças e Juan parecerá mais vivo ainda. Esse efeito Velázquez conseguiu através da cor, mais que do preciso desenho. E ela, agitada através da presença do borrão do pincel, que dá a impressão de um "movimento estático", a mesma impressão que temos ao ver um coisa viva em nossa frente, respirando, afetada por raios de luz, ocupando um espaço. Juan tem um extenso cabelo, mas não é possível contar nenhum fio. Se olharmos de perto, veremos que é uma série de borrões formando um grande êxtase de pura cor escura. Quando, contudo, a mão ou o cabelo são postos em relação com a totalidade do quadro, vistos como uma coisa só - que é como olhamos para as pessoas com quem conversamos, afinal ninguém fica constantemente reparando nas mãos e cabelos dos outros - uma ilusão de realidade mais aprimorada que o renascimento é acionada.

Esta diferença é no fundo uma espécie de "embate" épico na história da arte ocidental, que muito interessou a arte moderna e pré-moderna. Este é o embate entre cor e desenho, aqueles que privilegiam um em detrimento do outro, e que já assumiu diversas formas, como arte medieval versus renascimento, renascimento veneziano versus florentino, barroco versus renascimento, rococó versus neoclassicismo. Por que, a princípio, foi necessário um embate ao invés de uma comunhão de ambos? De fato, é possível pensar que essas escolas não queriam defender a cor ou o desenho, como bandeiras ideológicas. O que queriam, na verdade, era resolver um problema, a "contradição essencial da pintura, que reside no fato de que ela representa a profundidade em uma superfície" (GOMBRICH, 2013, p. 446). O embate ocorre porque essa contradição é essencial, ou seja não pode ser resolvida, e assim as escolas são obrigadas, pela própria forma material da tela, a optar por um lado, na intenção de representar o real. O real é um desenho real ou é uma impressão perspectiva real? De certa maneira, 
poderíamos dizer que os que privilegiam o desenho estão, de alguma maneira, do lado da informação, e fazem uma pintura mais "intelectual", no sentido de que as formas todas estão disponíveis, de forma imediatamente reconhecível. São "egípcios", nesse sentido. As cores estão contidas dentro dos traços do desenho; isso fica claro pela exposição das linhas escuras nos contornos. Do outro lado, aqueles que privilegiam as cores nublam essas linhas e submetem o desenho do corpo ou objeto a relação com a luz. A perspectiva existe, mas não é priorizada. Por vezes, para indicar os efeitos da luz, suas leis geométricas são infringidas. O efeito de ilusão de realidade, entretanto, pode ser, como vimos, talvez melhor realizado com esses truques irrealistas.

\section{Preparação para a arte moderna}

Quando nos aproximamos da arte do século XIX, nos aproximamos do ápice da "arte burguesa" de Bürger, da retomada da bidimensionalidade pré-renascentista (ou seja, do abandono da perspectiva) e de uma resolução para tal embate. Quem dará essa resolução são os impressionistas, para quem os "truques irrealistas" de intenção realista, como a mão de Juan, vão se intensificar em um estilo próprio, suficientemente radical para romper com os princípios renascentistas da perspectiva e da tridimensionalidade e fundar aquilo que chamaríamos de arte moderna.

Nosso terceiro estágio, a arte burguesa, tem produção e recepção individual, como vimos. A princípio podemos compreender o quadro ilusionista da arte cortesã predecessora como mais propenso a uma recepção individual, já que ele cria um mundo e assim se distingue do suporte (no caso, da parede da igreja, que abarca os espectadores da obra junto da obra, de forma claramente coletiva). Porém, esse mundo está no quadro para além do quadro, o suporte material. Ele é uma realidade em si mesma, imediatamente reconhecível: é o Monte Sinai, ou um descampado, uma marina, o paraíso ou o inferno. Nós todos entramos dentro dessa realidade que transcende o suporte do quadro, por isso Bürger chama essa recepção de coletiva ainda, mesmo que não seja mais através do culto. Ela é coletiva porque é "sociável", como diz Bürger. Habitamos juntos no mundo que ela desvela em seu interior. Além disso, a arte cortesã, como a arte sacra, "estão, ainda que cada qual a sua maneira, incorporadas à práxis vital do receptor", o que se dá por um motivo muito simples, por possuírem ainda uma "finalidade de uso" (BÜRGER, 2012, p.95). A obra cortesã, mesmo que possua uma finalidade menos explícita que a arte sacra, é "objeto de representação, serve à glória do príncipe e à autorrepresentação da sociedade cortesã" (Idem, p. 93).

Nada disso pode ser atribuído a arte burguesa, "que se situa fora da práxis vital" (Idem, p. 95). Esta ruptura não vem do nada, obviamente. Dentro da estrutura do mecenato cortesão que sustentava a profissão do 
artista e o dava finalidades, se engendra a produção individual da arte burguesa. A recepção individual, no entanto, é algo de novo, e só pode ocorrer por esse descolamento da arte da práxis vital humana. Mantém-se a arte como instrumento de autocompreensão da classe dominante, agora a burguesia. Porém, segundo Bürger, pelo próprio caráter desta classe a representação artística se modifica radicalmente:

\begin{abstract}
O burguês, reduzido na sua práxis vital a uma função parcial (ação ligada à racionalidade-voltada-para-fins), experimenta-se na arte como 'ser humano'; nela, ele consegue desenvolver a totalidade de suas capacidades, embora apenas sob a condição de que essa esfera permaneça rigorosamente divorciada da práxis vital. (BÜRGER, 2012, p. 95)
\end{abstract}

O pragmatismo burguês leva essa classe a um modo de vida diferente, por certo associada as mudanças tecnológicas vigentes na Europa a partir de dado momento e os primeiros passos dados em direção ao salto industrial de meados do século XIX. Assim como os objetos, utensílios, mercadorias se multiplicam, se discriminam e se separam em diversas funções parciais, os homens se dividem em profissões e especializações de caráter acima de tudo utilitário. Melhor discernimento de sua função, melhor eficiência na sua concretização. O termo "indivíduo" se refere àquilo que não pode ser dividido, contudo este "vai se fragmentando cada vez mais 'em seus papéis'" (HELLER, 2016, p.42). Como coloca Bürger, a arte burguesa se separa da práxis vital exatamente por uma nova configuração desta. Agora, ao contrário de antes, ela se caracteriza por uma rigorosa racionalidade voltada para finalidades. A arte não pode se encaixar em uma práxis como essa, visto que, tomada como meio para um fim, a arte é inútil. De fato, de que serve um quadro, dentro desta visão de mundo?

Serve apenas para a autocompreensão burguesa, o que significa: para ser o espaço, dentro desta vida extremamente utilitarista, onde o indivíduo pode desfrutar de uma condição sob a qual não há fins imediatos ou visíveis. Não é sem razão que um mundo prático produz uma individualidade igualmente não-prática, como reduto do "humano" que sobreporia nossas funções sociais. O que Bürger quer indicar, afinal, é que a arte burguesa "alivia", oferece um "momento de liberdade", de "descompromisso", e realoca as contradições sociais inerentes a um modo de vida inumano (pois inteiramente consumido pela praticidade) para uma "esfera ideal" e inofensiva (BÜRGER, 2012, p. 98). O problema afinal, como coloca Greenberg, é "a dificuldade de dar prosseguimento a uma tradição de cultura orientada para o lazer em uma sociedade orientada para o trabalho (GREENBERG, 2013, p. 54).

Esta separação de práxis vital e arte constitui de forma decisiva a autonomia da arte burguesa (Idem. p. 95-6). A soberania do autor e de sua individualidade, que se comunica em linha direta com o espectador, 
potencializa uma "comunidade de apartados", de caráter social diferente dos períodos anteriores. Produção e recepção individual da obra manifestam a autocompreensão da burguesia como antes de tudo o indivíduo burguês que sou do que a classe a qual pertenço. De fato, o caráter de classe se mascara; a obra fala sobre múltiplos assuntos, tudo pode ser tema, os estilos se tornam mais plurais, diversos como são os indivíduos criativos que produzem as obras. $\mathrm{O}$ mercado de arte nasce propriamente aqui e como todo o mercado intenso, necessita de uma constante produção nova, demandada pelo novo mecenas, não mais a aristocracia, mas a clientela.

A arte burguesa - oriunda do materialismo burguês, do seu pragmatismo e ceticismo, contrapostos ao idealismo aristocrata predecessor - revela o suporte da obra para o espectador. Nós vemos um quadro, um objeto móvel que colocamos sobre a lareira, na sala. Só depois olhamos para a realidade ilusória, e mesmo assim dentro do quadro, e não além dele. Ela decora um ambiente, conta ao visitante algo da personalidade ou do bom gosto de seu anfitrião.

Com o advento do impressionismo, a superação da perspectiva e consequentemente do realismo e até mesmo da representação, este caráter de objeto comum, de decoração, vai contaminar a forma própria da arte. Em outros termos: através do estilo da pintura se realçará o caráter de objeto da tela, aos poucos deixando a ilusão tridimensional interna ao quadro, a ideia de janela para um outro mundo.

Poderíamos chamar o Pantocrator de decoração? De certa forma, sim, mas devemos entender a decoração como algo mais do que a técnica do "design de interiores". Citamos anteriormente Greenberg, que falou em um "efeito decorativo", que na pintura de cavalete (arte burguesa e principalmente cortesã) era sobrepujado pelo efeito dramático-ilusório. A decoração é a adequação ou ressonância da obra em seu suporte material. Um efeito decorativo une a obra ao lugar onde ela é fruída. O museu, por mais bela que seja sua forma arquitetônica, é muitas vezes um portal para outros mundos, e cada quadro rompe com a parede em que habita. O cavalete, forma móvel de pintura, não está preso ao espaço em que pode ser visto. Auxilia também o autor a pintar ao ar livre e multiplicar os temas de sua obra e sua própria técnica. Porém, afirma Greenberg:

Na medida em que o artista achata a cavidade em nome da padronização decorativa e organiza seu conteúdo em termos de planaridade e frontalidade, a essência da pintura de cavalete que não é a mesma coisa que sua qualidade - está a caminho de ser comprometida (GREENBERG, 2013, p. 181).

É este caminho que perseguirão os pintores impressionistas. A arte moderna do século XX é onde este caminho os levou. Porém parece haver um problema aqui, já que Greenberg diz que o cavalete nasce como forma de ilusão, de obscurecimento de si, de efeito anti-decorativo, enquanto a arte 
burguesa, onde se localizam os impressionistas no século XIX, acontece em um momento de nascimento da mercadoria de arte, o quadro móvel como uma quinquilharia a ser depositada em qualquer lugar. Se o cavalete e sua mobilidade fomentam a ilusão, mas a arte burguesa acontece como conversão da obra em objeto, parece que falamos de caminhos distintos. Vamos ver como isso se resolve.

Para Greenberg os impressionistas "ortodoxos" usavam o mesmo tipo de toque nas pinceladas sobre todas as partes do quadro, de modo que mesmo tendo elementos e cores distintas, essas partes possuem uma espécie de tonalidade comum. No final, isso dá uma unidade ao quadro. As pinturas clássicas também possuem uma unidade, mas é interna: em imagens de santos e reis, é comum ver os diversos personagens dispostos de uma forma tal que se torna perceptível a harmonia geométrica intencionada pelo autor. A formação triangular ou piramidal, por exemplo, é corriqueira, com a figura de maior hierarquia (Jesus Cristo, Maria, o Rei) ocupando o que seria o topo da composição triangular, o centro de convergência do olhar, aquele lugar para onde, antes e acima de tudo, direcionamos instintivamente o nosso olho, controlado pela técnica do pintor. Nos impressionistas, contudo, a unidade não é interna ao quadro, mas esta sobre a própria superfície plana da tela. Não as figuras dentro, mas a própria bidimensionalidade da tinta distribuída democraticamente pela tela, é chamada primeiramente ao olhar, assumindo o lugar onde antes ficavam a realeza, terrena ou divina. Como a tela é apenas a tela, uma superfície, não é possível estabelecer grandes e explícitas hierarquias dos elementos pictóricos. No fundo, é como olhar para a própria tela em branco (onde todos os pontos dela parecem igualmente brancos), mas de uma maneira menos radical. Fica claro, contudo, que essa radicalidade ressoa retroativamente, ainda discreta, nos primeiros impressionistas, já germinando como possibilidade pela primeira vez aberta através da planaridade da tinta. Posteriormente, essa radicalidade enfim seria atingida.

A intenção do projeto impressionista, em linhas gerais, seria a de retratar na arte a perspectiva do olho humano quando vê coisas sensíveis. Vimos anteriormente que isso acarretaria, por vezes, em desenhar um pé visto de frente, ocultando seu calcanhar, pois é assim que o vemos dessa maneira. O mesmo princípio, em Velázquez, significou o desenho "borrado" da mão, do cabelo e das linhas que desenhavam Juan de Pareja, com o intuito de dar a impressão ágil que as imagens tem quando efetivamente as olhamos e não em quando a concebemos abstratamente. A questão aqui é a práxis desse olhar. O olhar anterior é abstrato, não está em lugar algum, como aquele que vê (da onde?) paraíso, inferno e mundo ao mesmo tempo, em um quadro de Bosch. É um grande esforço imaginativo conceber a si mesmo efetivamente olhando aquilo, na realidade. Não é o caso de Juan, que poderia se encontrar em nossa frente corriqueiramente. Por isso a tinta de Velázquez tem como questão própria adicionar em sua equação o olhar 
humano concreto. Nos impressionistas isso é levado ao limite. Seria óbvio que a representação do modo de ver humano chegaria a um limite, pois o aparato do olho e o da tela são bastante diferentes. Em dado momento, o impulso de aproximação vai acabar abandonando a representatividade e realçando a própria tela através de uma progressiva "deformação" da realidade ilusória representada (poderíamos imaginar o impressionismo como a pausa no meio de uma transformação do quadro figurativo em abstrato). Em dado momento, isso não se torna mais uma decorrência, mas uma intenção explícita. É o Modernismo. Como coloca Greenberg: "A arte realista, ilusionista, tinha dissimulado os meios, usando a arte para esconder a arte. O Modernismo usou a arte para chamar a atenção para a arte" (GREENBERG, 1986, p.98).

\section{Pressupostos para o ready-made}

Segundo Greenberg, a planaridade da tela e a consequente explicitação da condição de objeto da arte não são suficientes para equiparar arte e objeto. Para o crítico, é a bidimensionalidade da tela que se tornara o tema das pinturas modernistas e da arte abstrata. "Somente a superfície plana era única e exclusiva daquela arte" (Idem), a pintura. "Com os modernistas vemos o quadro antes de mais nada como pintura (Idem, p. 99), e a pintura se torna "mais consciente de si mesma" (Idem, p. 100), assim demarcando cada vez mais seu campo próprio. De fato, para Greenberg, o modernismo não rompeu com o passado (Idem, p. 104). Ele é um estágio do desenvolvimento da autoconsciência da arte e mais especificamente, para cada arte, o conhecimento sobre si própria. No caso da pintura, o conhecimento da pintura - o que quer dizer, da bidimensionalidade, proporcionada pela tela. Porém, é a bidimensionalidade, um conceito ótico, e não a tela, algo material e "objeto comum", o terreno próprio e constantemente demarcado pela arte moderna, segundo Greenberg. É de se esperar que, com tal perspectiva sobre a arte e a pintura, Greenberg não veja com bons olhos algo como o ready-made. De fato, ele não o via:

\footnotetext{
...para Greenberg, a arte continua a valer como força visual, e não é por outra razão que obras como a de Duchamp pouco lhe interessaram (NAVES, 2013, p.15) .
}

Duchamp também não concordaria muito com Greenberg, como relata em conhecida entrevista a Pierre Cabanne:

Desde Courbet, acredita-se que a pintura é endereçada à retina; este foi o erro de todo mundo. O frisson retiniano! Antes, a pintura tinha outras funções, podia ser religiosa, política, moral. (...) todo o século é completamente retiniano... (CABANNE, 2012, p.73) 
Algumas das primeiras obras de pintura feitas por Duchamp tem influência cubista, como o $\mathrm{Nu}$ Descendo a Escada $n^{\circ} 1$ (1911), que lhe deu algum renome. Sobre o cubismo, Greenberg diz que é "uma espécie de pintura ainda mais plana do que tudo o que a arte ocidental já tinha visto desde Cimabue" (GREENBERG, 1984, p. 101) e que "criou a pintura mais plana que a arte ocidental viu desde a época dos bizantinos" (Idem, 2013b, p. 378). Há também entre cubismo e dadaísmo, vertente em que Duchamp se engajará parcialmente depois, algumas linhas de contato, como por exemplo a colagem dadaísta (que, no entanto, acaba sendo, no dada, uma ponte para a tridimensionalidade). Aproximamos Duchamp da pintura "mais plana" do cubismo logo após trazer sua afirmação anti-retiniana para fazer uma constatação: a planaridade da pintura pode nos levar a uma afirmação de sua autonomia e separação do mundo da práxis, como em Greenberg, mas também pode nos levar a condição de objeto comum do quadro. De fato, Duchamp parece ter seguido esse segundo caminho. Sobre o seu $\mathrm{Nu}$ Descendo a Escada, Duchamp diz que:

\begin{abstract}
...eu queria criar uma imagem estática do movimento: o movimento é uma abstração, uma dedução articulada no interior de uma pintura, sem que se saiba se uma personagem real desce ou não uma escada igualmente real. No fundo, $o$ movimento é o olho do espectador que o incorpora ao quadro (CABANNE, 2012, p. 50, Nosso grifo).
\end{abstract}

Estava em jogo procedimento similar ao dos impressionistas, como destaca o grifo. Colocar na tinta a percepção do olhar humano sobre as formas do mundo. A deformação da tridimensionalidade ilusória que daí decorre traz, para Greenberg e os abstracionistas que ele admirava, uma maior separação de arte e práxis vital e a demarcação de um território próprio da arte (e, dentro da arte, da pintura) dentro do mundo. Com efeito, Duchamp diz: "quando se vê o que os abstracionistas fizeram depois de 40, é a pior coisa, eles são ópticos, estão realmente na retina até o pescoço!" (Idem, p. 74). Partindo dessa mesma deformação causada pela intenção de imitar o olhar concreto na forma-quadro, Duchamp encontrará, ao contrário dos autonomistas abstratos, o objeto-quadro.

É possível garimpar diferentes razões para Duchamp ter feito os ready-mades, mas é um ponto central a questão da realidade/ficcionalidade da obra, abordada segundo uma metodologia da objetificação das obras. O que queremos defender aqui é que há um coperterncimento entre a planaridade da tela e a objetualidade da tela, sua condição de objeto comum, do "mundo das coisas". Segue-se como um prosseguimento necessário da radicalidade do impressionismo, que por sua vez está contido nos princípios vigentes nas "belas artes" desde o elã representativo renascentista, a 
exposição da própria tela em branco $^{5}$, como comentamos anteriormente, sendo que o branco de sua tela importa, nessa acepção, tanto quando o madeira que o sustenta. Estamos falando de um objeto comum, descoberto, no entanto, através da arte. O ready-made é isso.

\section{Vanguarda}

O quarto tipo, posterior a arte burguesa, seria a vanguarda. A vanguarda se caracteriza por restabelecer a ligação que entre práxis vital e arte, rompida pela arte burguesa. "A arte novamente deve se tornar prática" (BÜRGER, 2012, p.96), o que de modo algum quer dizer assumir conteúdos práticos em si, mas efetivamente se deslocar para o seio da "práxis vital das pessoas", entrar em seu mundo como parte dele e não como um destacamento sublime. Bürger aqui parece seguir as considerações de Walter Benjamin em seu famoso ensaio A Obra de Arte na Era de sua Reprodutibilidade Técnica. No ensaio, é afirmado que a arte sempre possuiu um fundo religioso, fruto de sua produção material no mundo, e dele herdou uma condição de objeto de culto, uma aura, que a destaca das coisas terrenas, do mundo comum e prático. Esta aura da arte, que determina o fetiche com o "original", a obra de arte feita pelas próprias mãos do artista, chega a um momento de profunda crise no século XIX e XX com o advento de tecnologias de reprodução cada vez mais avançadas ${ }^{6}$.

As vanguardas, consoantes ao seu tempo, procuram "superar" a aura, devolvendo a arte ao mundo prático. Uma inserção na práxis vital burguesa não faria sentido, contudo, visto que neste estado de coisas em que encontravam os vanguardistas a razão para fins impera. Com efeito, não é do interesse vanguardista "integrar a arte a essa práxis vital", mas "organizar, a partir da arte, uma nova práxis vital" (BÜRGER, 2012, p. 97). Nesse sentido, ela parte da condição de destacamento da arte atingida pela arte burguesa, se valendo de sua insubmissão a práxis burguesa, contudo a reconfigurando, dando-a caráter transformativo, ao invés de contemplativo e conciliador. Uma arte que não mais alivia as pressões de um mundo pragmático e desumanizante, mas que as realça, que perturba, que joga o indivíduo em uma tensão insolúvel, a qual a resposta normalizante, aliviadora, só pode ser dada através da transformação social e política do mundo. Não é difícil encontrar nos manifestos das mais diversas tendências vanguardistas um vigoroso apelo político. No dadaísmo isso foi dominante

\footnotetext{
${ }^{5}$ Cf. ZIZEK, 2009, p. 163, onde se estabelece uma relação entre Kasimir Malevitch (o pintor que levou a radicalização da pintura planificada até o limite com seu Quadrado Negro e seu Quadrado Branco, este último especialmente condizente com nosso exemplo) e o ready-made de Duchamp, e se diz que "não há Duchamp sem Malevicth".

${ }^{6}$ Cf. BENJAMIN, 1994, p. 166-170.
} 
em sua gênese e se lia nos cartazes da Primeira Mostra Internacional Dada ${ }^{7}$, em 1920, em Berlim: "A arte está morta!", "Dada é a subversão deliberada dos valores burgueses", "Dada está do lado do proletariado revolucionário!". Em movimentos como o surrealismo, há envolvimento direto com o comunismo (cujo ápice é a parceria entre Breton e Trotski); no futurismo, há uma trágica adesão ao fascismo italiano.

Por causa dessa intrusão na práxis, se torna complicado sequer falar ainda em uma obra de arte, por isso Bürger denomina a produção da vanguarda de manifestação, e não obra (Idem, p. 98). Neste sentido, o ready-made, mesmo que seja o que é especificamente por ser denominado em público uma obra de arte, é de fato uma manifestação, e não obra, ou então um híbrido dentre os dois. O caso do ready-made é sui generis. Ele é uma manifestação cujo sentido é produzir uma "provocação", como diz Bürger, do conceito de arte, de sua assinatura - provocação que se dá exatamente pela simulação de ser uma obra de arte. Segundo Bürger,

\begin{abstract}
Pela provocação de Duchamp não apenas se desmascara o mercado da arte como instituição questionável em que a assinatura conta mais do que a qualidade da obra que ela subscreve, mas se põe radicalmente em questão o princípio mesmo da arte na sociedade burguesa, segundo o qual o indivíduo vale como criador da obra de arte. Os ready-made de Duchamp não são obras de arte, e sim manifestações (BÜRGER, 2013, p.100).
\end{abstract}

A vanguarda não nega apenas um estilo artístico que a precede, ela nega uma práxis vital e a própria instituição da arte (Idem, p. 96). Desse modo, as três linhas de definição dos tipos de Bürger - a finalidade, a produção e a recepção da obra de arte sacra, cortesã e burguesa - são subvertidos pela vanguarda. Não é mais possível falar em uma finalidade, pois se a arte é unida a práxis vital, "sendo estética a práxis e prática a arte" (Idem, p. 99), não se pode dizer que ela serve a algo - já que ela faz parte do mundo a que ela deveria servir (ou seja: ela agora é responsável pela definição do que será finalidade ou não, ao invés de ser meramente um meio para fins definidos de forma exterior a ela). Sobre a ideia de produção artística, a vanguarda retorna, por um lado, a acepção coletiva e confronta a ideia de gênio e assinatura, como atesta o ready-made. Qualquer um pode fazê-lo. De fato, o ready-made costuma "possuir" objetos manufaturados, como o urinol, a pá-de-neve, etc, "objetos produzidos em série", pelas mãos de trabalhadores industriais e máquinas; o próprio ready-made também é

\footnotetext{
${ }^{7}$ Cf. DACHY, 2006, contracapa. Esta posição de 1920, contudo, irá mudar. Em 1923, encabeçados por Kurt Schwitters, nomes como Hans Arp e Tristan Tzara assinam o Manifesto da Arte Proletária, de nome que só podemos interpretar como irônico, já que se lê que "a arte visa a maturidade da humanidade, não do proletariado ou da burguesia" e que "a arte que queremos não é nem burguesa e nem proletária" (p. 103).
} 
produzido em série pelo artista, que assina anonimamente. A aura e a "mão do artista" perdem validade. Mais além, como aponta Bürger (Idem, p.100), o caráter coletivo, em expressões mais radicais da vanguarda, é substituído pelo puro anonimato.

Quanto a recepção das obras, a categoria de recepção individual é negada (Idem, p. 101). Algumas obras poéticas possuem "caráter de receita" (Idem, p. 102) e podem ser repetidas pelos receptores tanto quanto pelos produtores. O próprio ready-made contém em si um chamado a sua repetição por parte do espectador, dado a sua facilidade de produção (basta apontar e denominar). Isso acaba criando uma produção que se confunde com a recepção (como dissemos na primeira página) e que, segundo Bürger, "não deve ser entendida como artística, devendo antes ser apreendida como parte de uma práxis vital libertadora". É claro que isso traz consigo "um perigo do solipcismo, da regressão aos problemas do sujeito individual" da arte burguesa, ainda vigente e soberana (BÜRGER, 2013, p. 102). Exatamente neste solipcismo parece cair aquilo que Bürger chama de "neovanguarda", uma "manifestação vazia de sentido, a permitir qualquer possível atribuição de sentido" (Idem, p.116).

Não é difícil ver como esse problema do solipcismo se desenha: para onde leva essa liberdade toda da práxis artística? Como efetivamente algo como o ready-made pode levar a uma práxis transformadora, sendo esta práxis, antes de tudo, para além da individualidade do produtor/receptor?

\section{Considerações finais}

Não é possível apontar aqui a solução para essa problema, mas acredito que a exposição da linha de desenvolvimento da arte na direção do objeto comum nos lega alicerces sólidos para pensar uma questão que, talvez, seja importante demais para ser resolvida "academicamente", através de textos como esse. A superfície bidimensional da folha branca não oferece os meios para essa resolução e é por isso que os artistas, mesmo aqueles que dependem de um puro conceito de arte, como Duchamp para justificar suas obras-já-prontas, não procuram concluir suas teorias em artigos, mas em manifestações. Contudo, se Bürger está certo e a vanguarda flui em direção a coletividade para escapar dos idealismos das artes predecessoras, é essa coletividade, e seu subsequente "anonimato", que deve ser responsável pela produção/recepção/finalidade de manifestações que respondam ao problema do solipcismo - que no fundo é o problema da individualidade burguesa e, sobretudo, da configuração de sua práxis vital "voltada à fins".

Como e em que sentido alterar coletivamente essa práxis vital é a questão. Em seu ensaio citado acima, na primeira versão, Benjamin fala em dois tipos de recepção de obras arquitetônicas, mas que também se relacionam a recepção de obras em geral: o recolhimento, que ele chama de recepção ótica (que ligamos sem maiores problemas ao "retiniano" do qual 
fala Duchamp), e a distração, "recepção tátil", que "se efetua menos pela atenção que pelo hábito" (BENJAMIN, 1994, p. 193).

Benjamin usa o termo "tátil" num sentido oposto ao de Greenberg, para quem a palavra designa ${ }^{8}$, em oposição ao "óptico", as obras clássicas que efetuam uma ilusão tridimensional da realidade - de modo que o espectador "entra" no quadro, transcendendo sua planaridade, e pode "tocar" a realidade mimetizada, como aqueles que confundiram Juan de Pareja com o verdadeiro Juan. O olho converte a tinta em realidade, em algo palpável, em algo que fundamentalmente não é a pintura para Greenberg. Em Benjamin o tátil é exatamente a característica desse modo de recepção distraído em que estamos inseridos no cotidiano, na vida comum, a tão repetida práxis vital de Bürger, que não é nada mais do que o mundo tridimensional, aquilo que do a arte ilusória busca recriar a experiência (de formas muito diversas, dependendo do estilo e da época). Não é necessário recriar essa experiência em uma obra, mas receber a obra por meio dessa experiência. O tátil não é somente o tridimensional (se não chamaríamos o ready-made de escultura), mas a recepção de um objeto no mundo prático através da práxis vital, do modo próprio de relação com as coisas que este mundo possui: este modo é a distração. Em outras palavras: se encontramos uma pessoa, que poderia ser Juan, e iniciamos uma conversa, não vamos reparar em suas mãos nem terá qualquer cabimento nos perguntarmos sobre as intenções de um autor.

Dentro deste mundo não paramos para observar a forma das coisas nem nos perguntar se elas são isso ou aquilo. Talvez este tenha sido o grande caminho transformador aberto pelo ready-made, independente da intenção de seu autor, que inclusive renegou o privilégio da intenção consciente do artista ${ }^{9}$ : não a ampliação infinita do elástico conceito de arte, englobando na neblina do ready-made todas as coisas existentes, mas sim o rompimento total desse conceito $^{10}$ (digamos que Duchamp puxou as extremidades do elástico até arrebentá-lo).

Com isso, não é a coisa que entra no mundo da arte, mas o que antes era "da arte" que passa a se referir ao mundo. Não o objeto no pedestal do museu, mas no mundo e em seu modo de lida própria, na distração, com certeza ligada a finalidades práticas. A transformação da práxis se insere nessas finalidades, nesse uso corriqueiro, distraído, e não fora dele, em um rompante de autoconscientização. Ao mesmo que a divisão entre arte e práxis vital se dissolve, o mesmo ocorre entre recolhimento e distração. Essa divisão, vinda de épocas passadas, tempos incólumes a violenta mudança que a indústria, a reprodução e a propaganda produziu em nós, não tem

\footnotetext{
${ }^{8}$ Cf. GREENBERG,1984, p. 100 e 2013, p. 195.

${ }^{9}$ Cf. DUCHAMP, 1984, p.73.

${ }^{10}$ Cf. BELTING, 2012, p. 291: "...o dadá revoltava-se contra o conceito de arte enquanto tal e os ready-mades de Duchamp desmascaravam esse conceito como uma ficção da sociedade burguesa".
} 
sustentação hoje. O recolhimento é anacrônico, fechado em grupos privilegiados, impossível de dizer qualquer coisa sobre o mundo que o cerca. Só nos resta pensar a distração não mais como passiva, mas como ativa, algo do qual podemos em algum nível se apossar, tornar nosso, de acordo com o interesse de nossas vidas, mesmo que isso não implique em convertê-la na consciência recolhida. Uma "distração atenta". A impressão de Bürger sobre "a ideia decisiva de Benjamin" (que não é necessariamente a sua):

Em lugar da recepção contemplativa característica do indivíduo burguês deve surgir uma recepção característica das massas, ao mesmo tempo distraída e racionalmente verificadora. Em lugar de basear-se no ritual, ela se funda, daí por diante, na política. (BÜRGER, 2013, p. 62, Nosso grifo).

A comparação de Bürger entre ritual e política, vinda de Benjamin, é oportuna, como é oportuna a relação entre a vinculação de arte e práxis vital da arte sacra, dada a bidimensionalidade de sua figura e a coletividade de sua recepção/criação. Tendo em vista essa proximidade se faz necessário a diferenciação, visto que a sociedade feudal e pré-feudal e sua respectiva práxis vital estão bastante distantes de nosso mundo - tanto o que em hoje vivemos quanto o que um dia queremos viver. 


\section{Referências bibliográficas}

BELTING, Hans. O fim da história da arte. São Paulo: Cosac Naify, 2012. BENJAMIN, Walter. Magia e técnica, arte e política: ensaios sobre literatura e história da cultura. São Paulo: Brasiliense, 1994.

BÜRGER, Peter. Teoria da vanguarda. São Paulo: Cosac Naify, 2013.

CABANNE, Pierre. Marcel Duchamp: engenheiro do tempo perdido. São Paulo: Perspectiva, 2012.

DUCHAMP, Marcel. O Ato Criador. In: BATTCOCK, Gregory (org.) A nova arte. São Paulo: Perspectiva, 1986.

DACHY, Marc. Dada: The Revolt of Art. London: Thames \& Hudson, 2006.

DANTO, Arthur. O descredenciamento filosófico da arte. Belo Horizonte: Autêntica, 2014.

FLORIÊNSKI, Pável. A perspectiva inversa. São Paulo: Editora 34, 2012.

GOMBRICH, Ernst Hans. A História da Arte. Rio de Janeiro: LTC, 2013.

GREENBERG, Clement. Arte e Cultura. São Paulo: Cosac Naify, 2013a.

Estética Doméstica. São Paulo: Cosac Naify, 2013b.

. A Pintura Modernista. In: BATTCOCK, Gregory (org.) A nova

arte. São Paulo: Perspectiva, 1986.

HELLER, Agnes. O Cotidiano e a História. São Paulo/Rio de Janeiro: Paz e Terra, 2016.

HUME, David. História Natural da Religião. São Paulo: Editora UNESP, 2005.

PEDROSA, Mário. Arte. Ensaios: Mário Pedrosa. São Paulo: Cosac Naify, 2015.

ZIZEK, Slavoj. Lacrimae Rerum: ensaios sobre o cinema moderno. São Paulo: Boitempo, 2009.

Autor(a) para correspondência: Filipe Ferreira Pires Völz, Universidade Federal do Rio de Janeiro, nstituto de Filosofia e Ciências Sociais, Largo São Francisco de Paula, 1, Centro, CEP 20051-070, Rio de Janeiro - RJ,Brasil. aquelefilipevolz@gmail.com 